\title{
DETECTION OF TRICHINELLA INFECTION IN SLAUGHTER HORSES BY ARTIFICIAL DIGESTION, ELISA AND PCR
}

\author{
VIVEROS N.*, ARRIAGA C.**, BANDA V.**, ORTEGA-PIERRES M.G.*** \& YÉPEZ-MULIA L.*
}

\begin{abstract}
Summary :
In this study we compared the sensitivity of molecular, serologic and parasitologic methods for diagnosis of equine trichinellosis in two abattoirs, one rural and one federal inspection type. Diaphragm muscle samples were obtained from 170 slaughter horses and examined by artificial digestion and PCR. Serum samples from these horses were also analyzed by ELISA. No Trichinella muscle larvae were detected by artificial digestion. However, specific antibodies against Trichinella were detected in $17 \%$ and $7 \%$ of the serum samples examined from the rural and the federal abattoirs respectively. By PCR, $15 \%$ and $2 \%$ of the samples from these two abattoirs were Trichinella positive.
\end{abstract}

KEY WORDS : trichinellosis, horse, PCR.

$\mathrm{H}$ uman trichinellosis outbreaks related to the consumption of horsemeat have been reported in France and Italy (Pozio et al., 1997). However, the diagnosis of equine trichinellosis by direct methods has proven to be difficult, possibly due to low infections in which the amount of sample analyzed may influence the parasite recovery, or to different parasite tissue predilection sites which depend on the level of infection (Gamble et al., 1996; Pozio et al., 1999). On the other hand, previous studies of horses naturally infected with Trichinella have shown that serologic assays such as ELISA and Western blot do not allow detection of all infected horses (Pozio et al., 1997; Yépez Mulia et al., 1999). In some of these cases more sensitive and specific diagnosis could be achieved using molecular techniques. In particular, amplification of Trichinella DNA by the polymerase chain reaction (PCR) has been successfully used to detect the parasite in experimentally infected mice and horses (Dupouy-Camet et al., 1991; Soulé et al., 1994; Uparanukraw \& Morakote, 1997).

* UIMEIP, Centro Médico Nacional Siglo XXI,

** CENID-Microbiología, INIFAP, SAGAR, Km 15.5 Carretera MéxicoToluca, México, D.F.

*** Dpto. de Genética y Biología Molecular CINVESTAV, IPN, México, D.F

Correspondence: C. Arriaga.

Tel.: 52-5-570-3100 ext. 30 - Fax: 52-5-570-4073.

E-mail: camila@micro.inifap.conacyt.mx
In order to compare the sensitivity of parasitologic, serologic and molecular methods in the diagnosis of equine trichinellosis, diaphragm tissue samples from 170 slaughter horses were examined by artificial digestion and PCR. In addition, serum samples from the same animals were analyzed by ELISA. The results suggest that the PCR technique could help to identify infected animals not detected by other diagnostic methods.

\section{MATERIAL AND METHODS}

\section{TISSUE AND SERUM SAMPLES}

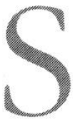
erum and diaphragm muscle tissue samples were collected from 170 horses slaughtered at two different abattoirs, one federal inspection type and one rural where naturally Trichinella infected horses had been previously detected. About $60 \mathrm{~g}$ of each sample were minced, $40 \mathrm{~g}$ for digestion and $1 \mathrm{~g}$ for PCR.

\section{ARTIFICIAL Digestion (AD)}

Tissue samples ( $40 \mathrm{~g}$ ) were digested in $1 \%$ pepsinHCL for three hours at $37^{\circ} \mathrm{C}$ and the larvae recovered by sedimentation as described by Dennis et al. (1970). Muscle tissue samples from a horse experimentally infected with $T$. spiralis in which 16 larvae per gram (LPG) had been detected, were used as positive control for this procedure.

\section{ELISA}

Serum samples diluted 1:20 were analyzed by ELISA using excretory/secretory (E/S) products as described by Yépez-Mulia et al. (1999).

\section{DNA EXTRACTION}

One $g$ of ground frozen tissue sample was incubated with $5 \mathrm{ml}$ of lysis buffer (0.5M Tris, 0.2M EDTA, $0.5 \%$ Sarkosyl and $10 \mu \mathrm{g} / \mu \mathrm{l}$ DNase free Rnase) for one hour at $37^{\circ} \mathrm{C}$ and with Proteinase $\mathrm{K}(100 \mu \mathrm{g} / \mu \mathrm{l})$, for two 
hours at $55^{\circ} \mathrm{C}$ and one hour at $65^{\circ} \mathrm{C}$. One fifth $(1 \mathrm{ml})$ of the supernatant was extracted with phenol-chloroform-isoamyl alcohol (25:24:1). The DNA was precipitated overnight with isopropanol and dissolved in $50 \mu \mathrm{l}$ of water.

\section{PCR}

PCR was performed in $50 \mu$ reaction volume containing $500 \mathrm{ng}$ of template DNA, $10 \mathrm{mM}$ Tris- $\mathrm{HCl}, 1.5 \mathrm{mM}$ $\mathrm{MgCl}_{2}, 5 \mathrm{mM} \mathrm{KCl}, 0.1 \%$ Triton X-100, $0.1 \%$ gelatin, $200 \mu \mathrm{M}$ each dNTP, $0.5 \mu \mathrm{g}$ of each pPRA primers (Dupouy-Camet et al., 1991) and 1.25 U of Taq polymerase (Amplitaq, Perkin-Elmer Corp, San Jose, Cal.). Amplification consisted of 30 cycles of one minute denaturation at $94^{\circ} \mathrm{C}$, one minute annealing at $55^{\circ} \mathrm{C}$ and two minutes extension at $72^{\circ} \mathrm{C}$, followed by seven minutes extension at $72^{\circ} \mathrm{C}$. The amplification products were separated by electrophoresis on a $2 \%$ agarose gel in Tris-acetate-EDTA buffer. Positive controls included DNA from T. spiralis muscle larvae (ML) and DNA from non infected horse muscle tissue spiked with 1,200 ML of $T$. spiralis. Negative controls were DNA from the non infected horse muscle tissue and a reagent control which included all PCR reagents except DNA.

\section{RESULTS}

\section{T} Trichinella $\mathrm{ML}$ were not recovered by $\mathrm{AD}$ in any of the diaphragm muscle tissue samples from slaughter horses examined although ML could be detected in samples of the experimentally infected horse. However, when specific antibodies against T. spiralis in the corresponding serum samples were evaluated by ELISA using E/S antigens, 14/80 (17\%) samples from the rural abattoir and 6/90 (7\%) from the federal abattoir gave positive OD values.

The limit of sensitivity of PCR with pPRA primers was determined using double dilutions of $500 \mathrm{ng}$ of DNA extracted from the non-infected horse tissue sample spiked with 1,200 ML. As little as $7 \mathrm{ng}$ of $T$. spiralis DNA (corresponding to $0.06 \mathrm{ML}$ ) were detected. In addition, a sensitivity of $0.045 \mathrm{ML}$ was determined

\begin{tabular}{cccc}
\hline $\begin{array}{c}\text { Type } \\
\text { of abattoir }\end{array}$ & $\begin{array}{c}\text { AD } \\
\text { Positive/Total }\end{array}$ & $\begin{array}{c}\text { ELISA } \\
\text { Positive/Total } \\
(\%)\end{array}$ & $\begin{array}{c}\text { PCR } \\
\text { Positive/Total } \\
(\%)\end{array}$ \\
\hline Rural & $0 / 80$ & $14 / 80(17)$ & $11 / 80(15)$ \\
Federal & $0 / 90$ & $6 / 90(7)$ & $2 / 90(2)$ \\
\hline
\end{tabular}

Table 1. - Results of artificial digestion (AD), ELISA and PCR in slaughter horses.

when DNA extracted from tissue samples of a naturally infected horse harboring nine LPG was used. When muscle tissue samples from slaughter horses were analyzed by PCR, 2/90 (2\%) of the federal abattoir and 11/80 (14\%) of the rural slaughterhouse gave the expected amplification products of 600 and/or 800 bp (Fig. 1) as well as an additional band of 1,200 bp in some of these samples (Fig. 1, lanes 5-9). These bands were also observed with the DNA from isolated T. spiralis ML and with DNA from horse tissue samples spiked with ML used as positive control (Fig. 1, lanes 10-11). No amplification products were observed with DNA from tissue samples of 157/180 slaughter horses (representative data are shown in Fig. 1, lanes 12 and 13). The data obtained in AD, ELISA and PCR are summarized in Table I.

\section{DISCUSSION}

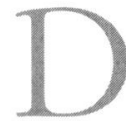
etection of Trichinella ML in infected horses by parasitologic methods has been difficult, probably due in some cases to low parasite burden and to the localization of the parasite in defined muscle tissue (Gamble et al., 1996; Pozio et al., 1999). In fact, only in recent years detection of T. spiralis in naturally infected horses has been reported (Arriaga $e t$ al., 1995; Pozio et al., 1997) and in these studies large muscle tissue samples were used. Considering that serologic methods (ELISA and Western blot) are not useful to identify all infected horses (Pozio et al., 1997, Yépez-Mulia et al., 1999), we evaluated PCR for diagnosis of trichinellosis in muscle tissue samples from slaughter horses, compared with AD and ELISA. Trichinella larvae were not isolated in these animals by

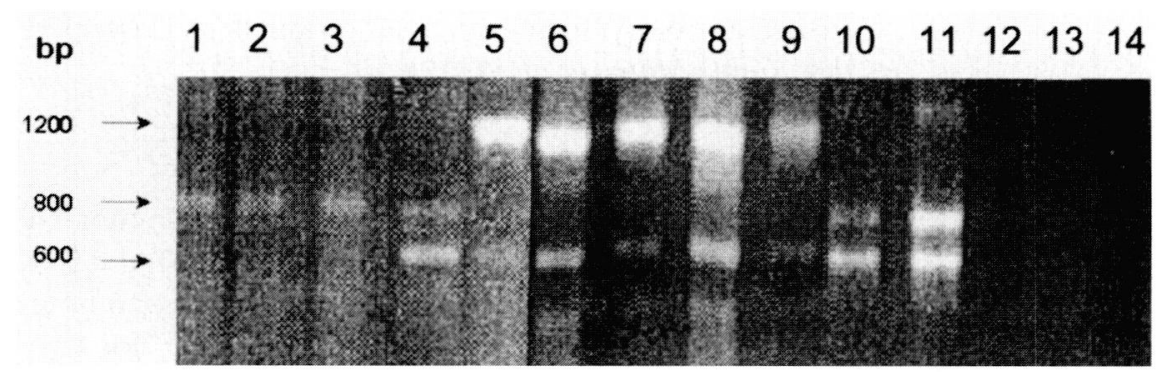

Fig. 1. - DNA samples amplified by PCR with pPRA primers. Lanes 1-4, positive samples from federal abattoir. Lanes 5-9, positive samples from rural slaughterhouse. Lane 10. Sample form non infected horse spiked with $T$. spiralis larvae. Lane 11. T. spiralis DNA. Lane 12, negative sample from federal abattoir. Lane 13, negative sample from rural abattoir. Lane 14 , control reagents. 
AD. However, by PCR some horse tissue samples gave the specific amplification products of 600 and $800 \mathrm{bp}$. In some cases, a band of 1,200 bp was observed, in agreement with the finding of Dick et al. (1992) using DNA samples from different Trichinella isolates. Since no amplification was observed in tissue samples of the non infected horse and in other samples of slaughter horses it seems that the animals positive by PCR were indeed infected. Considering that the PCR used in this study allowed the detection of $7 \mathrm{ng}$ of DNA which correpond to $0.06 \mathrm{~T}$. spiralis $\mathrm{ML}$, it is possible that the parasite load in the diaphragm of these animals was below the limit of detection of $\mathrm{AD}$ since no Trichinella larvae could be found in these tissue samples. It is also possible that the partial destruction of the larvae by the horse immune system did not allow larvae recovery by $\mathrm{AD}$ although DNA could still be detected by PCR.

On the other hand, only three of the 20 animals positive by ELISA gave the expected amplification products by PCR. Some of the positive results obtained only by ELISA could be due to cross reactivity of TSL- 1 antigens with other nematode antigens (De Ayuela et al., 2000) as such antigens are highly represented in E/S products. In addition, other 11 samples negative in ELISA gave positive results by PCR, suggesting an early or late infections in those animals in which low antibody levels were possibly present as has been previously shown by Yépez-Mulia et al. (1999). These results provide further evidence that ELISA is not an adequate diagnostic test for equine trichinellosis.

Although it was not possible to recover the parasite in the diaphragm samples examined, it is possible that in other tissues the number of ML was higher, as mentioned by others (Gamble et al., 1996; Pozio et al., 1999). Head muscles are at the present recommended for the diagnosis of horse trichinellosis, however diaphragm tissue samples are still used for inspection in many abattoirs. Thus, it is important to have a very sensitive diagnostic method such as PCR that would allow the identification of infected horses not detected by other methods.

\section{ACKNOWLEDGEMENTS}

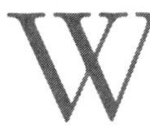

e are grateful to Arturo Pérez-Taylor for his excellent technical assistance in the preparation of this manuscript.

\section{REFERENCES}

Arriaga C., Yépez-Mulia L., Viveros N., Adame L.A., Lichtenfels J.R., Zarlenga D., Benitez E. \& Ortega-Pierres M.G. Detection of Trichinella spiralis muscle larvae in naturally infected horses. Journal of Parasitology, 1995, 81, 781-783.
De Ayuela M.A., Romaris F., Ubeira F.M., Rama S., MartínezFERnÁNDEZ A. \& Bolás F. Possible presence of common tyvelose-containing glycans in Trichinella LI larvae and embryonated eggs of several nematodes. Abstract of the 10th International Conference on Trichinellosis. Fontanebleau, France. August 20-24, 2000, p. 73.

Dennis D.T., Despommier D.D. \& Davis N. Infectivity of the newborn larva of Trichinella spiralis in the rat. Journal of Parasitology, 1970, 56, 974-977.

Dick T.A., Lu M., DE Vos T. \& MA K. The use of polymerase chain reaction to identify porcine isolates of Trichinella. Journal of Parasitology, 1992, 78, 145-148.

Dupouy-Camet J., Soulé C., Gulllou, J.P., Rouer E., Souza S.L., ANCElLE T. \& Benarous R. Detection of repetitive sequences of Trichinella spiralis by the polymerase chain reaction in experimentally infected mice. Parasitology Research, 1991, 77, 180-182.

Gamble H.R., Gajadhar A.A. \& Solomon M.B. Methods for the detection of trichinellosis in horses. Journal of Food Protection, 1996, 59, 420-425.

Pozio E., Tamburrini A., Sacchi L., Gomez-Morales M.A., Corona S., Goffredo E. \& La Rosa G. Detection of Trichinella spiralis in a horse during routine examination in Italy. International Journal of Parasitology, 1997, 27, 1613-1621.

Pozio E., Paterlini F., Pedarra C., Sacchi L., Bugarini R., GofFREDO E. \& BONI P. Predilection sites of Trichinella spiralis larvae in naturally infected horses. Journal of Helmintbology, 1999, 73, 233-237.

Soulé C., Gulllou J.P., Vallet C., Perret C. \& Calamel M. Trichinella spiralis larvae, detected by PCR in the blood of an experimentally infected horse, in: Trichinellosis. Campbell W.C., Pozio E. \& Bruschi F. (eds), Istituto Superiore di Sanitá Press, Rome, 1994, 101-104.

Uparanukraw P. \& MORAKOTE N. Detection of circulating Trichinella spiralis larvae by polymerase chain reaction. Parasitology Research, 1997, 83, 52-56.

Yépez-Mulia L., Arriaga C., Viveros N., Adame A., Benitez E. \& Ortega-Pierres M.G. Detection of Trichinella spiralis in slaughter horses by artificial digestion and immunoenzymatic methods. Veterinary Parasitology, 1999, 81, 57-68. 